\title{
The impact of male-killing bacteria on the evolution of aphidophagous coccinellids
}

\author{
Michael E.N. MAJERUS \\ Department of Genetics, University of Cambridge, Cambridge, CB2 3EH, UK; e-mail: m.majerus@gen.cam.ac.uk
}

Key words. Coccinellids, biased sex ratios, male-killing, cytoplasmic bacteria, reproductive manipulation

\begin{abstract}
Many aphidophagous coccinellids harbour male-killing bacteria. These maternally inherited bacteria kill males early in embryogenesis, female offspring of infected mothers gaining a large resource advantage from the consumption of their dead brothers. In this paper, the diversity of male-killing bacteria and their coccinellid hosts will be briefly reviewed. Thereafter, the impact that invasion by male-killers has on coccinellid hosts will be addressed in two ways. First, the selective effects due to the loss of male progeny, and the intra-genomic conflict resulting from the cytoplasmic inheritance of the bacteria will be considered. Reductions in mitochondrial diversity, effects on clutch sizes and the evolution of male-killer suppresser systems will be discussed. Second, the impact of female biased population sex ratios on the evolution of reproductive strategies and the primary sex ratio will be investigated. Preliminary results suggesting changes in male investment per copulation, reductions in female testing behaviour of males, and male biases in the progenic sex ratios of some uninfected male lines will be presented. Avenues for future work will be outlined.
\end{abstract}

\section{INTRODUCTION}

Many aphidophagous coccinellids harbour male-killing bacteria (Majerus \& Hurst, 1997). These maternally inherited bacteria kill males early in embryogenesis, female offspring of infected mothers gaining a large resource advantage from the consumption of their dead brothers (Hurst \& Majerus, 1993).

The bacteria that kill males are taxonomically diverse, having been found within the genus Spiroplasma (Mollicutes) (Hackett et al., 1986, Hurst et al., 1999a, Majerus et al., 1999), the Flavobacteria-Bacteroides group (Hurst et al., 1997a, 1999b) and the gamma and alpha subdivisions of the Proteobacteria (Werren et al., 1986, 1994, Hurst et al., 1999c, Majerus, 2003a). Examples from all these groups have been recorded in aphidophagous coccinellids (Table 1).

The basic parameters that determine whether a male-killer will invade a host population are $a$, the vertical transmission efficiency of the bacterium; $s$, the direct fitness effect of the bacterium on female hosts; and $b$, the fitness compensation (that is the increase in fitness of mainly infected females that compensates for the death of their brothers) that accrues to daughters of infected females as a result of the death of their brothers (Hurst et al., 1997b). Then, invasion is possible if:

$$
b>1 /[a(1+s)]>1 \text {. }
$$

Thereafter, the bacterium will theoretically increase in prevalence, $p$, to a stable equilibrium of:

$$
p=[a b(1+s)]-1 /[b(1+a s)-1] .
$$

The fitness compensation, $b$, may result from reduced inbreeding loss among female progeny of infected females, increased resources for neonates from consumption of dead male sibling hosts, or reduced resource com- petition due to reduced density following the death of male sibling hosts.

Aphidophagous coccinellids are a hot-spot for malekiller invasion because $b$ is high as a result of eggs being laid in clutches, neonate larvae habitually eating any unhatched eggs, and survival of neonate larvae being low due to the ephemerality of aphid prey (Banks, 1955; Wratten, 1973, 1976; Majerus, 1994; Majerus \& Hurst, 1997). This last factor, the ephemerality of aphids, means that $b$ will vary both temporally and spatially, with the consequence that the stable equilibrium prevalence predicted by basic models of male-killing (Hurst, 1991; Hurst et al., 1997b) will rarely be achieved and maintained. Rather, we may expect that the prevalence will increase following periods of high resource advantage when aphids are scarce, and decrease when the fitness advantage declines as a result of high aphid availability (Majerus, 2003a).

These changes are not symmetrical. If no resource advantage accrues to daughters of infected females (i.e. their survival is the same as that of daughters of uninfected females), the decline in male-killer prevalence will be due to the imperfect vertical transmission of the bacterium and direct costs of infection. As $a$ is $>0.9$ for most male-killers in coccinellids (Majerus, 2003a) and $s$ is negative (i.e. there is a direct fitness cost of infection), but only mildly so in most cases (Hurst et al., 1994; Majerus 2003a), the decline in $p$ will be slow. Conversely, the increase in prevalence due to high resource advantage may be very rapid if aphids are very scarce, as the fitness benefit for those neonate larvae that receive the additional resources from consuming one or more of their dead brothers will then be inflated (Majerus, 2003a).

Temporal and spatial variation in the prevalence of male-killers has been demonstrated in both $A$. bipunctata 
TABLE 1. Male-killing in ladybirds. (Adapted and amended from Majerus 1999, 2003a.)

\begin{tabular}{|c|c|c|c|c|c|}
\hline Host species & Countries & Agent & Prevalence & Evidence* & References \\
\hline Adalia bipunctata & $\begin{array}{l}\text { England, Scotland, } \\
\text { Holland, Denmark, } \\
\text { Luxembourg, Belgium, } \\
\text { France, Germany, } \\
\text { Poland, Russia, Kyr- } \\
\text { gyzia, Norway }\end{array}$ & Rickettsia & $0.01-0.23$ & $\begin{array}{l}\text { f-bsr; lhr; mi; as; hs; } \\
\text { m; sDNA; PCR }\end{array}$ & $\begin{array}{l}\text { Hurst et al., 1992, 1999a; } \\
\text { Werren et al., 1994; Majerus et } \\
\text { al., 2000; Schulenburg, 2000; } \\
\text { Zakharov \& Shaikevich, 2001; } \\
\text { Majerus, 2003a; Tinsley, 2003; } \\
\text { Majerus, unpubl. data }\end{array}$ \\
\hline Adalia bipunctata & $\begin{array}{l}\text { Germany, Russia, } \\
\text { Sweden }\end{array}$ & $\begin{array}{l}\text { Spiroplasma } \\
\text { (Group VI) }\end{array}$ & $0.03-0.53$ & $\begin{array}{l}\text { f-bsr; lhr; mi; as; hs; } \\
\text { m; sDNA; PCR }\end{array}$ & $\begin{array}{l}\text { Hurst et al., 1999a; Majerus et } \\
\text { al., 2000; Tinsley, } 2003\end{array}$ \\
\hline Adalia bipunctata & Russia, Sweden & $\begin{array}{l}\text { Two strains of } \\
\text { Wolbachia }\end{array}$ & $0.02-0.1$ & $\begin{array}{l}\text { f-bsr; lhr; mi; as; hs; } \\
\text { m; sDNA; PCR }\end{array}$ & $\begin{array}{l}\text { Hurst et al., 1999c; Majerus et } \\
\text { al., } 2000\end{array}$ \\
\hline Adalia 10-punctata & Germany, England & Rickettsia & 0.09 & $\begin{array}{l}\text { f-bsr; lhr; mi; as; hs; } \\
\text { m; sDNA; PCR }\end{array}$ & $\begin{array}{l}\text { Schulenburg et al., 2001; Maje- } \\
\text { rus, 2003a; Majerus, unpubl. } \\
\text { data }\end{array}$ \\
\hline $\begin{array}{l}\text { Harmonia } \\
\text { axyridis** }\end{array}$ & $\begin{array}{l}\text { Japan, Russia, South } \\
\text { Korea, }\end{array}$ & $\begin{array}{l}\text { Spiroplasma } \\
\text { (Group VI) }\end{array}$ & $0.02-0.86$ & $\begin{array}{l}\text { f-bsr; lhr; mi; as; hs; } \\
\text { m; sDNA; PCR }\end{array}$ & $\begin{array}{l}\text { Matsuka et al., 1975; Zakharov } \\
\text { et al., 1996; Majerus et al., } \\
\text { 1998, 1999; Majerus, 2001, } \\
\text { 2003a }\end{array}$ \\
\hline $\begin{array}{l}\text { Coleomegilla } \\
\text { maculata }\end{array}$ & U.S.A. & Flavobacterium & 0.23 & $\begin{array}{l}\text { f-bsr; lhr; mi; as; } \\
\text { sDNA; PCR }\end{array}$ & Hurst et al., 1996, 1997a \\
\hline Adonia variegata & Turkey, England & Flavobacterium & $0.07-0.13$ & $\begin{array}{l}\text { f-bsr; lhr; mi; as; } \\
\text { sDNA; PCR }\end{array}$ & $\begin{array}{l}\text { Hurst et al., 1999b; Majerus, } \\
\text { unpubl. data }\end{array}$ \\
\hline $\begin{array}{l}\text { Harmonia } \\
\text { 4-punctata }\end{array}$ & France & Flavobacterium & 0.11 & $\begin{array}{l}\text { f-bsr; lhr; mi; as; } \\
\text { sDNA; PCR }\end{array}$ & $\begin{array}{l}\text { Majerus \& Tinsley, unpubl. } \\
\text { data }\end{array}$ \\
\hline $\begin{array}{l}\text { Hippodamia 15- } \\
\text { signata }\end{array}$ & U.S.A. & Unknown & Unknown & f-bsr; lhr; mi & Shull, 1948 \\
\hline $\begin{array}{l}\text { Cheilomenes } \\
6 \text {-maculatus** }\end{array}$ & Japan & $\gamma$-proteobacterium & $0.13 * * *$ & f-bsr; lhr; mi; as; PCR & Majerus, 2001, 2003a \\
\hline Coccinula sinensis & Japan & Flavobacterium & 0.23 & f-bsr; lhr; mi; as; PCR & Majerus \& Majerus, 2000 \\
\hline Coccinula crotchi & Japan & Flavobacterium & 0.23 & $\begin{array}{l}\text { f-bsr; lhr; mi; as; } \\
\text { sDNA; PCR }\end{array}$ & Majerus, unpubl. data \\
\hline Propylea japonica & Japan & Rickettsia & $0.07-0.26$ & f-bsr; lhr; mi; as; PCR & Majerus, 2001, 2003a \\
\hline $\begin{array}{l}\text { Anisosticta 19- } \\
\text { punctata }\end{array}$ & England & $\begin{array}{l}\text { Spiroplasma } \\
\text { (Group VI) }\end{array}$ & 0.31 & $\begin{array}{l}\text { f-bsr; lhr; mi; as; } \\
\text { sDNA; PCR }\end{array}$ & Tinsley, 2003 \\
\hline $\begin{array}{l}\text { Coccinella 11- } \\
\text { punctata }\end{array}$ & Egypt & Unknown & 0.5 & $\begin{array}{l}\text { f-bsr; lhr; mi; sDNA; } \\
\text { PCR }\end{array}$ & $\begin{array}{l}\text { Elnagdy \& Majerus, unpubl. } \\
\text { data. }\end{array}$ \\
\hline $\begin{array}{l}\text { Coccinella } \\
7 \text {-punctata }\end{array}$ & England & Unknown & $<0.01$ & f-bsr; lhr & Sloggett, pers. comm. \\
\hline $\begin{array}{l}\text { Coccinella } \\
\text { 7-punctata brucki }\end{array}$ & Japan & Unknown & 0.13 & f-bsr; lhr; mi & Majerus, unpubl. data \\
\hline Calvia 14-punctata & England, Canada & Unknown & $<0.05$ & f-bsr; lhr, mi & Majerus, 2003a \\
\hline
\end{tabular}

*Evidence given as: $\mathrm{f}-\mathrm{bsr}=$ female biased sex ratio; $\mathrm{lhr}=$ low egg hatch rate in infected lines; $\mathrm{mi}=$ maternal inheritence; as = antibiotic sensitive; $\mathrm{hs}=$ heat sensitive; $\mathrm{m}=$ microscopy; $\mathrm{sDNA}=\mathrm{DNA}$ sequencing; $\mathrm{PCR}=$ detection of symbiont using symbiontspecific PCR reaction. ** Additional taxa of male-killing bacteria suspected (for H. axyridis - S.S.M. Hassan, pers. comm.; for $C$. 6-maculatus - K. Niijima, pers. comm.). ${ }^{* * *}$ Prevalence of male-killer uncertain due to presence of male rescue gene (see text).

and $H$. axyridis (Table 1) (Hurst et al., 1992; Majerus et al., 1998; Majerus, 2003a; Tinsley, 2003). In addition, multiple male-killers have been reported in A. bipunctata; up to four male-killers occurring in the same population (Majerus et al., 2000) and are suspected in both $H$. axyridis and Cheilomenes sexmaculatus (S.S.M. Hassan, pers. comm.; K. Niijima, pers. comm.). Thus, while malekiller prevalences of between 0.05 and 0.5 may be considered "normal" in coccinellids, higher prevalences, with consequently more female biased population sex ratios, also occur. For example, in $H$. axyridis, populations with
$80 \%$ females have been recorded (Majerus, 2003a), and in A. bipunctata, some Russian populations have over $70 \%$ females (Majerus et al., 2000; Zakharov, pers. comm.), while in southern Sweden, samples comprising up to $81 \%$ females have been reported (Tinsley, 2003). In each of these instances, the sex ratio biases have been shown to be due to high male-killer prevalences (Majerus et al., 2000; Majerus, 2001; Tinsley, 2003).

Here I briefly consider some of the effects of the presence of male-killing bacteria on the evolution of coccinellid hosts. Such effects may be a direct consequence of 
male-killer infection of individual coccinellids, or a response to changes in coccinellid population sex ratios and demography as a result of male-killer presence.

\section{DIRECT EFFECTS OF THE PRESENCE OF MALE-KILLERS}

\section{Male-killers and host mitochondrial genomes}

Invasion of a ladybird population will have an effect on the genetic constitution of hosts, as a direct consequence of the male-killer's mode of inheritance. Because malekilling bacteria and host mitochondria are both maternally inherited, an invading male-killer will have an association with the mitotype of the first ladybird that it invades (mitotype A). Assuming that invasion is initiated by a single event and that the male-killer has imperfect vertical transmission, Johnstone \& Hurst (1996) found that mitotype A will spread through the population as the malekiller increases in frequency. Furthermore, as some uninfected hosts with mitotype A will be generated each generation due to the imperfect vertical transmission of the symbiont, eventually mitotype A will spread through the entire population. Variation in mtDNA will thus be severely reduced.

Mitotype selective sweeps will have consequences for researchers who use mtDNA sequences in work on population structure and demography, gene flow and possibly phylogenetic reconstruction. The major implication of this is that it means that corroborative nuclear sequence analyses are essential in work on aphidophagous coccinellids, so many of which are, or have been, affected by male-killers.

\section{Selection on host nuclear genomes: vertical transmission, suppressers and clade selection}

Theoretically, the "best" male-killer would have perfect vertical transmission, kill all infected males and have no fitness cost, or better still confer a fitness benefit on infected females (Randerson, 2000). This "best" malekiller does not seem to occur among those that infect coccinellids. In none is the vertical transmission efficiency perfect (Table 1), in A. decempunctata and Cheilomenes sexmaculatus, infected males sometimes survive to adulthood (Schulenburg et al., 2001; Majerus, 2003a), and in all coccinellid cases studied (but not in one butterfly species (Jiggins et al., 2002)), male-killers have been shown to have direct costs on infected females (Matsuka et al., 1975; Hurst et al., 1994; Majerus, 2003a). Why is this the case?

At the route of considerations of the impact of malekillers on their hosts' nuclear genomes is the question of virulence. In this context, male-killers are unusual because selection might be expected to favour increased virulence in male hosts and decrease virulence in female hosts. In coccinellids, where the success of a male-killer is a consequence of the consumption of male-killed eggs by male-killer bearing females, this is obvious.

Virulent male-killer strains that kill male embryos very early in embryogenesis will be more successful than less virulent strains that kill later, because the advantage to consuming neonate larvae is greatest when male death has occurred early and little of the egg soma has been used by the developing embryo. Thus, we might expect selection for rapid replication rate in male hosts so that male death is effected at the earliest possible time. However, if replication rate is equally rapid in female hosts, this may impose higher direct costs on infected females. Here the selection for increased virulence appears to be positive in male but negative in female hosts, and we may expect symbiont replication to be more rapid in males than females.

The situation may not be so simple as this if both virulence and vertical transmission efficiency in females are dependent on bacterial density. Selection for high transmission efficiency from infected females is likely to oppose selection for decreased virulence in female progeny. Consequently, in female hosts we should perhaps expect male-killer replication rate to be the result of a trade-off between increased vertical transmission and decreased virulence (Majerus, 2003a). It may be as a consequence of these antagonistic selection pressures acting on male-killers in female hosts that vertical transmission efficiency is not perfect. For male-killers in male hosts, there is no such trade-off, selection simply favouring increased virulence. Empirical evidence is badly needed to shed further light on these speculations.

The question of why vertical transmission efficiency of early male-killers in coccinellids is imperfect now becomes crucial. The vertical transmission efficiencies of the four male-killers found in Moscow samples of $A$. bipunctata vary considerably (Rickettsia $=0.719$; Wolbachia $\mathrm{Z}=0.856$; Wolbachia $\mathrm{Y}=0.988$; Spiroplasma $=$ 0.984-1.0 in three lines) (Majerus et al., 2000). This suggests that the vertical transmission of these bacteria is a function of the male-killers themselves, not of their host. Conversely, in two species of butterfly, Acraea encedon and Acraea encedana, both of which are infected with the same strain of Wolbachia (showing no difference in over 5000 nuclear and mitochondrial nucleotides sequenced), vertical transmission efficiencies of 1.0 and 0.96 respectively have been recorded (Jiggins et al., 1998, 2000, 2001). Here, the vertical transmission appears to be host dependent. From these two examples it seems likely that the vertical transmission of a male-killer is dependent on the interaction between a symbiont and its host, with the role of each varying between systems, and the environment probably also influencing the interaction.

Of course, if the vertical transmission efficiency of a male-killer that has successfully invaded a host population is perfect, the male-killer will spread to fixation. In this case, unless the host develops some form of suppressor system, such as a rescue gene that prevents the pathological effect of the symbiont of males (Majerus 2003a), the host population will become extinct due to the lack of males. The likelihood of a male-killer driving its host to extinction will depend on a number of factors in addition to the vertical transmission efficiency. These include the number of females that a male can inseminate, the level of density-dependent population size regulation and the likelihood that male-killer suppressers will 
evolve. Male ladybirds are highly promiscuous, mating many times with different females. In $A$. bipunctata and $H$. axyridis, males typically mate with 20-30 females, and some mate with even more (Majerus, 1994), so shortage of males is only likely to have a marked effect on fertilisation in very female biased populations. Densitydependent factors, that influence population size in the form of prey availability, intra-specific competition for food and cannibalism, will also operate in ladybirds, affecting both pre-adult survival and adult reproductive output (Majerus, 1994; Dixon, 2000). Here again, the presence of such factors will reduce the probability of population extinction. The likelihood that male-killer suppressers will evolve in coccinellids is difficult to assess, but at least one coccinellid, Menochilus sexmaculatus, has a male-killer suppresser gene (see below). Therefore, as a result of these factors, it is unlikely that population extinction occurs commonly in ladybirds due to malekillers.

\section{Male-killer suppressers and male biases}

The uniparental, maternal inheritance of early malekilling symbionts means that these cytoplasmic elements are in conflict with most of the biparentally inherited nuclear genomes of their hosts (Hurst, 1991). Selection may thus be expected to promote any biparentally inherited (or paternally inherited) nuclear genes that resisted the mortality imposed on the nuclear genome by the pathological action of the male-killer. This intra-genomic conflict resulting from the selective death of nuclear genomes by cytoplasmic male-killers may lead to the evolution of suppresser systems that act against the malekillers.

In the case of male-killer suppresser systems, it is feasible to imagine that suppression could be achieved by killing the male-killer, by reducing its vertical transmission efficiency, or by nullifying the pathological action of the male-killer, either by blocking the male-recognition system of the symbiont, or by preventing the killing act (Majerus, 1999).

In C. sexmaculatus, which harbours a male-killing $\gamma$-proteobacterium (Majerus, 2001), a male-killer suppresser was discovered when the sex ratio of progeny from individual females altered following second or third matings with different males (Majerus, 1999). Analysis showed that the suppresser acted to block the pathological effect of the male-killer: i.e. survival of infected male embryos is due to a rescue gene. The rescue gene is inherited as a unifactorial dominant allele, and is transmitted by both males and females (Majerus, 2003a). The malekilling symbiont is not killed by the rescue gene, nor is its vertical transmission efficiency significantly reduced.

It is notable that male rescue in C. sexmaculatus is caused by a dominant allele of a single gene. Hurst et al. (1997b) have proposed that polygenes that acted to delay death in infected males would not spread. Their argument is based upon the assumption that death early in embryogenesis is beneficial to the symbiont as a result of resource reallocation to surviving siblings (mainly infected females), and so is particularly pertinent to aphi- dophagous coccinellids. As retardation of male death would allow greater consumption of the resources in an egg by the embryo, the resource reallocation benefits that accrued to infected female siblings would be reduced. Thus, even if some males survived due to the retardation of male death, this gain would be off-set by the reduced kin benefit to female siblings from those males that still died. It therefore seems likely that a male rescue system cannot evolve gradually: such a system will only spread if it is controlled by a major gene that rescues most or all of the infected males that carry it (Majerus, 1999).

\section{RESPONSE TO CHANGES IN POPULATION SEX RATIO}

\section{Sexual selection and sex role reversal}

Male-killers that distort population sex ratios may have profound impact on the reproductive strategies of their hosts. In most sexually reproducing organisms, the operational sex ratio is biased towards males, females being the limiting sex. The result is that usually males compete with one another for access to mates, while females are choosy. However, in female biased populations, the strength of selection for males to compete and females to choose will be reduced. The greater the female bias, the greater this reduction will be, although the levels of promiscuity of each sex will affect the precise reduction. If the sex ratio is very strongly distorted, so that the number of males limits the rate of reproduction, selection will favour sex role reversal, where females compete and males choose.

Such a reversal of sexual roles has been reported for the sibling species of Acraea butterflies, A. encedon and $A$. encedana (Jiggins et al., 1999). Here, populations in which the sex ratio is more than 20:1 in favour of females have been reported. Males are more promiscuous than females, but are limited in the number of copulations they can achieve in their lives, with the result that many females die virgin. The result is that in both these species, females compete on lekking sites, and males visit the aggregations of females to mate.

In coccinellids, reported sex ratio biases due to malekilling are less severe than in $A$. encedon and $A$. encedana, and a male is capable of more lifetime matings than is a male Acraea. Consequently, the selection pressures for females to compete and males to choose will be less severe in ladybirds than in acraeines. However, theoretically there should still be variance in the levels of male competition and female choice resulting from the sex ratio biases caused by male-killing, and in cases of high male-killer prevalence, sex role reversal, with elements of female competition and male choice, is plausible.

Empirical evidence of the effect of sex ratio biases on sexual selection in ladybirds is sparse, but some does exist. In $H$. axyridis, Osawa \& Nishida (1992) showed that levels of female mating preference were variable, both within and between populations. Although this work did not consider population sex ratio, sample sites were in Central Honshu, where $H$. axyridis is known to harbour a 
male-killing Spiroplasma at variable prevalence (Majerus, 2001). Furthermore, the work also demonstrated an element of male choice in the system.

Recent work on A. bipunctata has provided more direct evidence of the impact of population sex ratio on levels of female choice. In this species, females show a variety of rejection behaviours when mounted by males, including kicking back at the male's genitalia, leg-lifting, abdomen waggling when running, rolling and dropping (Majerus, 1994). These rejection behaviours serve to test the fitness of males (Haddrill, 2001). Using samples in which the population sex ratio ( $\%$ female) varied from $49 \%$ to $72 \%$, a correlation was found between sex ratio and the length of time that females used rejection behaviour to test males that mounted them. Thus, females from more female biased populations attempted to reject males less than those from less female biased populations: a reduction in female choosiness occurred when males were rarer (Majerus, unpubl. data).

\section{Changes in male investment per copulation}

The behaviour of male $A$. bipunctata also varies as a result of variation in population sex ratios. In this species, copulation consists of three phases: the rejection phase (usually, but not always seen), the "twisting" phase during which a spermatophore is constructed, and the "rocking" phase in which sperm is transferred into the spermatophore and thence into the female's spermatheca (Ransford, 1997). Once the rocking phase has been completed, some males remain on the female for a second or even a third mating cycle, manufacturing and inserting sperm into additional spermatophores (Ransford, 1997). Males are thus capable of multiple ejaculations within a single copulation.

In tests on samples with different male-killer prevalences and population sex ratios, male investment per copulation was correlated to the sex ratio (proportion of males). Thus variance in male investment was effected through changes in the mean number of spermatophores transferred per copulation, not by reducing the number of spermatozoa per spermatophore (Majerus, 2003a). In low male-killer prevalence populations (Cambridge, U.K. prevalence $=0.06-0.11$; Ulan Ude, Russia prevalence $=$ 0.03 ), an average of approximately 1.8 spermatophores were transferred per copulation, while in St. Petersburg samples, with a prevalence of 0.5 , the average was only 1.2. Here then, where male competition is less intense, males on average invest fewer resources in each copulation. A similar reduction in male investment has been demonstrated in highly female biased populations of the butterfly Hypolimnas bolina (Dyson \& Hurst, 2004).

\section{Selection on the primary sex ratio}

On the basis of sex ratio theory, biases in the sex ratio towards one sex or the other should lead to selection in favour of the rarer sex (Fisher, 1930; Hamilton, 1967). Where the presence of male-killers has biased a population sex ratio in favour of females, selection in favour of the production of males should occur, with the intensity of the selection being correlated to the degree of sex ratio bias (Majerus, 1999). Therefore, in populations that are female biased due to the presence of male-killers, selection will favour a bias in the primary or secondary sex ratio towards males. Theoretically, any mechanism that favoured males over females should invade a female biased population, as long as the greater fitness of males resulting from their higher mating success offset the reduction in the number of females produced. However, the dynamics of such a system are complicated in ladybird populations that are female biased due to malekilling because the main advantage to male-killing is the fitness increase that accrues to female offspring of infected mothers when they eat their dead brothers. The complication arises because the fitness change resulting from the rarer sex, males, will depend on whether the female is infected with a male-killer. An uninfected female that produced more male than female progeny would increase her fitness through the extra matings that her sons would gain. Conversely, an infected female that produced more sons than daughters would suffer a decrease in fitness if the loss of these extra sons (killed by the male-killer) were not offset by the fitness increment gained by the daughters that she did produce through eating these additional dead brothers.

Empirical evidence for male biases in species with male-killers is sparse. However, some has been documented. In four species, two ladybirds ( $H$. axyridis and Coccinula sinensis) and two butterflies (A. encedon and $A$. encedana), significantly male-biased families have been recorded (Owen \& Chanter, 1969; Jiggins, 2000; Majerus \& Majerus 2000; Majerus, 2003a). Work into the heritability of such male biases would be profitable.

\section{The sex ratio and sexually transmitted diseases}

One obvious consequence of a female biased sex ratio is its effect on the transmission of sexually transmitted diseases (STD). In insects in which both sexes are promiscuous, such as ladybirds, the rate of spread of an STD will be greater in sex ratio biased populations than in those in which the sex ratio is close to parity. Thus, in populations that are female biased due to the presence of male-killers, STDs will reach higher prevalences than in those with 1:1 sex ratios. This is because in female biased populations, males, due to their scarcity, will have more mating partners and so more opportunity to both contract and pass on the disease (Majerus, 2003b).

Ladybirds are known to suffer from sexually transmitted mites of the genus Coccipolippus (Hurst et al., 1995). These mites attach to the underside of their host's elytron from which they suck haemolymph. Eggs are laid under the elytron and subsequent nymphs migrate to the posterior tip of the abdomen, transferring to new hosts during host sexual contact. In A. bipunctata, Coccipolippus hippodamiae can have a devastating effect on female hosts, who become sterile about three weeks after becoming infected (Webberley et al., 2002). Interestingly, C. hippodamiae has highest recorded prevalences in $A$. bipunctata populations with highly female biased sex ratios, in Poland, Russia and Germany. Tinsley (2003) has shown that in Scandinavia, mite prevalence is high in 
southern Sweden, where male-killer prevalence is high, but is absent from northern Sweden and north Norway, where male-killer prevalence is low.

Adalia bipunctata also hosts a suit of sexually transmitted fungi of the Laboulbeniales group. The best studied of these is Hesperomyces virescens, which is found mainly on the ventral surface of males and the dorsal surface of females. Transmission occurs mainly during sexual contact (Welch et al., 2001) and again the rate of transmission will increase in highly female biased populations. The effect of infection on host fitness has not been studied.

\section{CONCLUSION}

Male-killers are common in aphidophagous coccinellids. In over half the species of ladybirds that have all the ecological and behavioural criteria that promote male-killing (Majerus \& Hurst, 1997) and that have been assayed for male-killers, they have been found. Moreover, despite this field still being in its infancy, evidence that both the presence of these uniparentally inherited sex ratio distorters, and the population sex ratio biases that they cause can impact on the reproductive biology of their hosts is accumulating. It is doubtful that complete range of impacts has yet been uncovered. One intriguing observation suggests that more influences of these symbionts on their hosts have yet to be unearthed. This observation concerns a possible association between male-killers and colour pattern polymorphism in aposematic insects.

The theory of aposematism (true warning colouration) predicts that aposematic species should be monomorphic. Yet a number of aposematic species, including ladybirds, such as A. bipunctata, A. 10-punctata, H. axyridis and Propylea japonica, and butterflies, such as $A$. encedon and Danaus chrysippus, are highly polymorphic. Every one of these polymorphic species in which male-killers have been sought have been shown to harbour at least one. One wonders whether this is merely a coincidence.

\section{REFERENCES}

BANKS C.J. 1955: An ecological study of Coccinellidae associated with Aphis fabae Scop. on Vicia faba. Bull. Entomol. Res. 46: 561-587.

Dixon A.F.G. 2000: Insect Predator-Prey Dynamics: Ladybird Beetles and Biological Control. Cambridge University Press, Cambridge, ix $+257 \mathrm{pp}$.

Dyson E.M. \& HuRst G.D.D. 2004: Persistence of an extreme sex ratio bias in a natural population. Proc. Natl. Acad. Sci. USA 101: 6521-6525.

FISHER R.A. 1930: The Genetical Theory of Natural Selection. Oxford University Press, Oxford, $272 \mathrm{pp}$.

Hackett K.J., Lynn D.E., Williamson D.L., Ginsberg A.S. \& Whiтcомв R.F. 1986: Cultivation of the Drosophila spiroplasma. Science 232: 1253-1255.

Haddrill P.R. 2001: The Development and Use of Molecular Genetic Markers to Study Sexual Selection and Population Genetics in the 2-spot Ladybird, Adalia bipunctata (L.). Unpubl. Ph.D. thesis, Cambridge University.

Hamilton W.D. 1967: Extraordinary sex ratios. Science 156: 477-488.
Hurst G.D.D. \& Majerus M.E.N. 1993: Why do maternally inherited micro-organisms kill males? Heredity 71: 81-95.

Hurst G.D.D., Majerus M.E.N. \& Walker L.E. 1992: Cytoplasmic male killing elements in Adalia bipunctata (Linnaeus) (Coleoptera: Coccinellidae). Heredity 69: 84-91.

Hurst G.D.D., Purvis E.L., Sloggett J.J. \& Majerus M.E.N. 1994: The effect of infection with male-killing Rickettsia on the demography of female Adalia bipunctata L. (two spot ladybird). Heredity 73: 309-316.

Hurst G.D.D., Sharpe R.G., Broomfield A.H., Walker L.E., Majerus T.M.O., ZaKharov I.A. \& Majerus M.E.N. 1995: Sexually transmitted disease in a promiscuous insect, Adalia bipunctata. Ecol. Entomol. 20: 230-236.

Hurst G.D.D., Hammarton T.C., Obrycki J.J., Majerus T.M.O., Walker L.E., Bertrand D. \& Majerus M.E.N. 1996: Male killing bacterium in a fifth ladybird beetle, Coleomegilla maculata (Coleoptera: Coccinellidae). Heredity 77: 177-185.

Hurst G.D.D., Hammarton T.M., Bandi C., Majerus T.M.O., Bertrand D. \& Majerus M.E.N. 1997a: The diversity of inherited parasites of insects: the male-killing agent of the ladybird beetle Coleomegilla maculata is a member of the Flavobacteria. Genet. Res. 70: 1-6.

Hurst G.D.D., Hurst L.D. \& Majerus M.E.N. 1997b: Cytoplasmic sex-ratio distorters. In O'Neill S.L., Hoffmann A.A. \& Werren J.H. (eds): Influential Passengers. Oxford University Press, Oxford, pp. 125-154.

Hurst G.D.D., Von de Schulenburg H.G., Majerus T.M.O., Bertrand D., Zakharov I.A., Baungaard J., VölkL W., Stouthamer R. \& Majerus M.E.N. 1999a: Invasion of one insect species, Adalia bipunctata, by two different malekilling bacteria. Insect Mol. Biol. 8: 133-139.

Hurst G.D.D., Bandi C., Sacchi L., Cochrane A.G., Bertrand D., Karaca I. \& Majerus M.E.N. 1999b: Adonia variegata (Coleoptera: Coccinellidae) bears maternally inherited Flavobacteria that kill males only. Parasitology 118: 125-134.

Hurst G.D.D., Jiggins F.M., Schulendurg J.H.G.v.D., Bertrand D., West S.A., Goriacheva I.I., ZaKharov I.A., Werren J.H., Stouthamer R. \& Majerus M.E.N. 1999c: Male-killing Wolbachia in two species of insect. Proc. R. Soc. Lond. (B) 266: 735-740.

HURST L.D. 1991: The incidences and evolution of cytoplasmic male-killers. Proc. R. Soc. Lond. (B) 244: 91-99.

Jiggins F.M., Hurst G.D.D. \& Majerus M.E.N. 1998: Sex-ratio distortion in Acraea encedon (Lepidopera: Nymphalidae) is caused by a male-killing bacterium. Heredity 81: 87-91.

JigGins F.M., Hurst G.D.D. \& Majerus M.E.N. 1999: Sex ratio distorting Wolbachia causes sex role reversal in its butterfly host. Proc. R. Soc. Lond. (B) 267: 69-73.

Jiggins F.M., Hurst G.D.D., Dolman C.E. \& Majerus M.E.N. 2000: High prevalence male-killing Wolbachia in the butterfly Acraea encedana. J. Evol. Biol. 13: 495-501.

Jiggins F.M., Hurst G.D.D., Schulenburg J.H.G.v.D. \& MaJerus M.E.N. 2001: Two male-killing Wolbachia strains coexist within a population of the butterfly Acraea encedon. Heredity 86: 161-166.

Jiggins F.M., Randerson J.P., Hurst G.D.D. \& Majerus M.E.N. 2002: How can sex ratio distorters reach extreme prevalences? Male-killing Wolbachia are not suppressed and have near-perfect vertical transmission efficiency in Acraea encedon. Evolution 56: 2290-2295.

Johnstone R.A. \& HuRst G.D.D. 1996: Maternally inherited male-killing microorganisms may confound interpretation of mtDNA variation in insects. Biol. J. Linn. Soc. 58: 453-470.

Majerus M.E.N. 1994: Ladybirds. New Naturalist Series 81. Harper Collins, London, 368 pp. 
Majerus M.E.N. 1999: Simbiontes hereditarios causantes de efectos deletéreos en los artrópodos. Deleterious endosymbionts of Arthropods. In Melic A., De Haro J.J., Méndez M. and Ribera I. (eds): The Evolution and Ecology of Arthropods. Sociedad Entomologica Aragonera, Zaragosa, Spain, pp. 777-806 (In Spanish and English).

Majerus M.E.N. 2003a: Sex Wars: Genes, Bacteria, and Sex Ratios. Princeton University Press, Princeton, New Jersey, $280 \mathrm{pp}$.

MAJERUS M.E.N. 2003b: A new dimension to sex wars: microbes that benefit female hosts. Microbiol. Today 30: 68-70.

MaJerus M.E.N. \& Hurst G.D.D. 1997: Ladybirds as a model system for the study of male-killing symbionts. Entomophaga 42: $13-20$.

Majerus M.E.N. \& Majerus T.M.O. 2000: Female-biased sex ratio due to male-killing in the Japanese ladybird Coccinula sinensis. Ecol. Entomol. 25: 234-238.

Majerus M.E.N., Schulenburg J.H.G.v.D. \& ZaKharov I.A. 2000: Multiple cause of male-killing in a single sample of the 2 spot ladybird, Adalia bipunctata (Coleoptera: Coccinellidae) from Moscow. Heredity 84: 605-609.

MajERus T.M.O. 2001: The Evolutionary Genetics of Malekilling in the Coccinellidae. Ph.D. thesis, University of Cambridge.

Majerus T.M.O., Majerus M.E.N., Knowles B., Wheeler J., Bertrand D., Kuznetzov V.N., Ueno H. \& Hurst G.D.D. 1998: Extreme variation in the prevalence of inherited malekilling microorganisms between three populations of the ladybird Harmonia axyridis (Coleoptera: Coccinellidae). Heredity 81: 683-691.

Majerus T.M.O., Schulenburg J.H.G.v.D., Majerus M.E.N. \& HuRST G.D.D. 1999: Molecular identification of a malekilling agent in the ladybird Harmonia axyridis (Pallas) (Coleoptera: Coccinellidae). Insect Mol. Biol. 8: 551-555.

Matsuka M., Hashi H. \& OKada I. 1975: Abnormal sex ratio found in the lady beetle Harmonia axyridis Pallas (Coleoptera: Coccinellidae). Appl. Entomol. Zool. 10: 84-89.

Osawa N. \& Nishida T. 1992: Seasonal variation in elytral colour polymorphism in Harmonia axyridis (the ladybird beetle): the role of non-random mating. Heredity 69: 297-307.

Owen D.F. \& Chanter D.O. 1969: Population biology of tropical African butterflies. Sex ratio and genetic variation in Acraea encedon. J. Zool. Lond. 157: 345-374.

Randerson J.P., Smith N.G.C. \& Hurst L.D. 2000: The evolutionary dynamics of male-killers and their hosts. Heredity $\mathbf{8 4}$ : $152-160$.
Ransford M.O. 1997: Sperm Competition in the 2-spot Ladybird, Adalia bipunctata. Unpubl. Ph.D. thesis, University of Cambridge.

Schulenburg J.H.G.v.D. 2000: The Evolution and Dynamics of Male-killing in the Two-spot Ladybird Adalia bipunctata L. (Coleoptera: Coccinellidae). Unpubl. Ph.D. thesis, University of Cambridge.

Schulenburg J.H.G.v.D., Habig M., Sloggett J.J., Webberley M., Bertrand D., Hurst G.D.D. \& Majerus M.E.N. 2001: The incidence of male-killing Rickettsia (alpha proteobacteria) in the 10-spot ladybird, Adalia decempunctata L. (Coleoptera: Coccinellidae). Appl. Environ. Microbiol. 67: 270-277.

Shull H.F. 1948: An all-female strain of lady beetles with reversions to normal sex ratio. Am. Nat. 82: 241-251.

TinsLey M.C. 2003: The Ecology and Evolution of Male-killing Bacteria in Ladybirds. Unpubl. Ph.D. thesis, University of Cambridge.

Welch V.L., Sloggett J.J., Webberley K.M. \& Hurst G.D.D. 2001: Short range clinal variation in the prevalence of a sexually transmitted fungus associated with urbanisation. Ecol. Entomol. 26: 547-550.

Webberley M.K., Hurst G.D.D., Busko J. \& Majerus M.E.N. 2002: Lack of parasite mediated sexual selection in a ladybird/sexually transmitted disease system. Anim. Behav. 63: $131-141$.

Werren J.H., Skinner S.W. \& Huger A.M. 1986: Male-killing bacteria in a parasitic wasp. Science 231: 990-992.

Werren J.H., Hurst G.D.D., Zhang W., Breeuwer J.A.J., Stouthamer R. \& Majerus M.E.N. 1994: Rickettsial relative associated with male killing in the ladybird beetle (Adalia bipunctata). J. Bacteriol. 176: 388-394.

WratTEN S.D. 1973: The effectiveness of the coccinellid beetle, A. bipunctata (L.) as a predator of the lime aphid, Eucallipterus tiliae (L.). J. Anim. Ecol. 42: 785-802.

Wratten S.D. 1976: Searching by Adalia bipunctata (L.) (Coleoptera: Coccinellidae) and escape behaviour of its aphid and cicadellid prey on lime (Tilia $\times$ vulgaris Hayne). Ecol. Entomol. 1: 139-142.

ZaKharov I.A. \& Shaikevich E.V. 2001: The Stockholm populations of Adalia bipunctata (L.) (Coleoptera: Coccinellidae) a case of extreme female-biased population sex ratio. Hereditas 134: 263-266.

Zakharov I.A., Hurst G.D.D., Chernysheva N.E. \& Majerus M.E.N. 1996: The maternally inherited bacterium causing female bias in the Petersburg population of Adalia bipunctata does not belong to the genus Rickettsia. Russ. J. Genet. 32: 1303-1306.

Received May 31, 2005; revised and accepted August 1, 2005 